European journal of American studies

\title{
American Schools of Interdisciplinarity: History and Literature Programs and Their Early Twentieth-Century Traditions
}

Hélène Cottet

\section{OpenEdition \\ Journals}

Electronic version

URL: https://journals.openedition.org/ejas/11410

DOI: $10.4000 /$ ejas. 11410

ISSN: 1991-9336

\section{Publisher}

European Association for American Studies

\section{Electronic reference}

Hélène Cottet, "American Schools of Interdisciplinarity: History and Literature Programs and Their Early Twentieth-Century Traditions", European journal of American studies [Online], 11-1 | 2016, document 2, Online since 02 June 2016, connection on 08 July 2021. URL: http:// journals.openedition.org/ejas/11410 ; DOl: https://doi.org/10.4000/ejas.11410

This text was automatically generated on 8 July 2021 .

Creative Commons License 


\title{
American Schools of Interdisciplinarity: History and Literature Programs and Their Early Twentieth-Century Traditions
}

\author{
Hélène Cottet
}

1 Wherever there is a scholarly attempt to consider history and literature together, the question of interdisciplinarity comes into play, along with the related issues of institutional practice and reform. Standing for scholarly and pedagogical innovation, interdisciplinarity is typically presented as an unprecedented attempt to de- or re-structure an outdated organization of knowledge, namely, in this case, the constitution of history and literature as separate disciplines in the university. The problem with this common equation between interdisciplinarity and innovation is that it partially obscures the history of interdisciplinarity itself, and the ways, however marginal, in which it has already been instituted. With respect to the joint study of literature and history in the United States, this institution of interdisciplinarity can be traced back to the same period in which a culture of specialization and professionalization emerged in the American university. Such an inheritance, however, tends to be lost whenever interdisciplinarity is presented precisely as a reaction against tradition.

2 Before we review a few of the contexts in which an interdisciplinary tradition emerged in the United States with respect to the study of history and literature, we have to address this "mildly transgressive" appeal of interdisciplinarity, grounded in the belief that "what is holding things back is disciplinarity, the persistence of the academic silos known as departments" (Menand 95). In his book on the history and issues of American higher education, The Marketplace of Ideas: Reform 
and Resistance in the American University, Louis Menand, professor of English at Harvard, registers the urgency but also the anxiety with which interdisciplinarity is presently advocated, revealing a latent desire on the part of self-conscious academics to cross over into "the larger culture" (123). What Menand explains, however, is that this very desire is in itself a consequence of the freedom afforded by the disciplines themselves. Conferring professional status and authority to the practitioners of a given field, the discipline as "self-governing and largely closed community of practitioners who have an almost absolute power to determine the standards for entry, promotion, and dismissal in their fields" (104-105) makes possible an autonomy that can also be invoked to transcend that discipline, Menand argues: "In a profession in which freedom of thought is both a matter of intense piety and an institutional mechanism for maintaining professional autonomy, the ability to identify with something beyond official organizations and institutions and even disciplines is a pressing one" (116). Thus interdisciplinarity may be one way of going "beyond" institutional limitations, but the very autonomy that authorizes the trend towards interdisciplinarity seems a crucial result of the disinterestedness made possible by the discipline itself-which regulates knowledge internally rather than "by the extent to which it meets the needs of interests external to the field" (105). For Menand, moreover, interdisciplinarity cannot be worked into true institutional reform so long as the main function of the academic system, "both for purposes of its continued survival and for purposes of controlling the market for its products," remains "the production of the producers" (105). When the work of the university is assessed in such pragmatic terms, disciplinarity remains key, since it is inside the discipline that the future professional is both credentialed and specialized (something that Menand has lamented). ${ }^{i}$ Interdisciplinarity, on the other hand, while it may produce knowledge, does not produce its producers, at least not in a way that can guarantee their recognition on a national level, where it matters.

3 The aporetic situation that Menand seems to delineate is that interdisciplinarity cannot present itself as a reaction against disciplinarity without at the same time acknowledging the dominant influence held by that model of knowledge, which both makes the interdisciplinary impulse possible and enforces the standards of professionalization against which it fails. The logic of this is compelling, but we want to suggest that this domination of the disciplinary model is also what might have rendered the alternative interdisciplinary models of education, affiliation, or credentialization somewhat illegible. In an attempt to recover some of them, we must revise slightly the larger narrative that Menand unfolds to explain the interdisciplinary aporia. Menand accounts for the persistent constraints of disciplinary organization by explaining that the present American university, with its distribution of knowledge according to academic fields, is still the "heir" of that "particular historical moment" when the modern university emerged, "between 1870 and 1915" (97). The univocity of 
that period's historical significance and influence is problematic, for the decisive moment in the establishment of the new university culture can also be seen as the last moment of indecision. In other words, such a foundational period could also be invoked as the seminal moment of resistance to disciplinarity from which interdisciplinary endeavors up to this day may have inherited some of their traditions, their forms, or their expressions of institutional dissent. In the case of the interdisciplinary study of literature and history, this heritage becomes apparent when Menand's periodization is revised to focus on the beginning of the twentieth century and to include the 1920s. This slight rearrangement, as we will see, is necessary to account for the delayed manner in which the pressure of disciplinarity caught up with the study of American literature, and to constitute that very delay as a moment of reference for the interdisciplinary study of history and literature in America.

4 Menand's chronology leaves out, indeed, the case of American literature, which was recognized as a discipline only in the 1920s, which means that during the period of professionalization that Menand describes the study of American literature remained one of the few provinces left to the generalist-as opposed to the specialist-and as such remained linked to examinations of American history. While efforts to redefine the field called that previous scholarly range into question, many of those who would reestablish it later within the American Studies movement would look back to the past, and especially to the period from 1900 into the 1920s, to locate the tradition which they sought to uphold. This does not mean that such a period serves as the reassuring proof that interdisciplinarity can thrive in a context of professionalization and specialization-the point is not to alleviate what Menand has called "the anxiety of interdisciplinarity," but rather to show that that anxiety is historical, both because it has already been experienced in the past, and because it has been expressed by a revisitation of the past. This revisitation is what tends to be lost whenever interdisciplinarity is equated with innovation, or when the institutional history of the American university is collapsed under a teleological account. Yet some of the very models for the interdisciplinary study of history and literature today are inherited from that long beginning of the twentieth century, which is eventually what we hope to show by comparing Columbia's very recent History and Literature program with Harvard's, launched a century earlier.

\section{Moments of Indecision: From The Reinterpretation of American Literature to American Studies}

5 The case of the study of American literature is particular enough and can slightly disrupt Menand's assessment of the period 1870-1915 and show not only how the process of specialization raised the question of interdisciplinarity, but also how deep-rooted is the project of a joint 
consideration of America's literature and history. The constitution of American literature as a sub-discipline within departments of English was belated, and took place only in the 1920s, when the American Literature Group was created within the Modern Language Association (itself founded in 1883), and launched its own journal. ${ }^{\text {ii }}$ It took therefore a relatively long time for the study of American literature to be structured according to the criteria of professionalization and specialization upheld by the modern research university-perhaps the most telling indicator of this delay is the fact that Johns Hopkins, founded in 1876, and the model for future research universities in America, recruited its own American literature specialist only in 1941. iii The story of American literature's slow academic recognition has been told elsewhere (Vanderbilt; Shumway; Renker), and is fascinating in its own right, but what is interesting for our purpose is this lag-time between the birth of the research university and the emergence of American literature as a semi-autonomous field. The time of this differal is the period during which the undisciplined study of American literature came to be closely associated with history.

6 This is what Claudia Stokes has observed in Writers in Retrospect: The Rise of American Literary History, 1875-1910, where, focusing on the same decades in which Menand locates the birth of the research university, she describes the emergence of the study of American literature "under the aegis of literary history" (17). Linking the rise of American literary history to the "culture of retrospection" (17) that accompanied preparations for the centennial celebrations of the Declaration of Independence, Stokes analyzes the ways in which the history of American literature was used to give Americans a sense of their national past. This civic purpose would long remain at the heart of the study of American literature, but the historic propositions on which it relied were soon at odds with the new scientific culture of the university. As history became an academic discipline, the turn it took towards a scientific paradigm at the end of the nineteenth century led to the discredit of Great Men theories, which held individual geniuses as the main forces behind history. This created an asynchronicity of sorts between the agenda of historical scholarship and the demands of American literature scholars, whose very legitimacy still depended on proving the greatness of a few national authors that could compare to the figures consecrated in other cultures. The debate which this generated between, on the one hand, advocates of a depersonalized history that would concentrate on the larger and material forces at work in a culture, and, on the other hand, persistent seekers of genius and extra-ordinary excellence, is one which informed discussions about American literary scholarship throughout the end of the nineteenth century and the beginning of the twentieth. It would also influence the politics of American literary scholarship. As a more overtly elitist preoccupation with masters and masterpieces became constitutive of the critical discourse that informed the disciplinary practice of American literature, we will see later that some of those who turned 
towards interdisciplinarity as upholding a more democratic commitment to the "whole" of American culture would have to go back in time and search a pre-disciplinary past to constitute their own tradition. While this is not the place to retrace extensively this debate and its ramifications, the claim made by the critic Henry Seidel Canby in the first issue of American Literature (1929) that "[l]iterature is not the expression of all the people by all the people for all the people" (Canby 81), and that the study of American literature should therefore focus on its masterpieces, is proof enough that this discussion was ongoing by the time American literature was being constituted as an academic field.

7 Canby made this claim in his review of The Reinterpretation of American Literature (1928), a collaborative study directed by Norman Foerster, a member of the New Humanist movement. This collection of essays is still considered as a defining work in the history of the field. ${ }^{\text {iv }}$ For our purpose, this work is relevant precisely for the undefined or undetermined character that it assumes owing to its collaborative nature: within its pages, among its authors, a crucial hesitation is dramatized between the competing value of criticism and history for the study of American literature. Even while the project of an American literary history is being upheld, it seems torn between the now rival demands of literature and of history, as is perhaps best illustrated by the calculated effect of dissymmetry in the titles of the two essays that end the volume, "American History and American Literary History" by Arthur M. Schlesinger (Sr.), and "American Literary History and American Literature" by Harry Hayden Clark. Canby's review, which takes on an official quality for appearing in the new professional journal, consists essentially in taking sides between those two final essays, and his emphatic claim quoted above is meant as a deliberate rejection of historian Schlesinger's propositions.

8 Schlesinger, whose New Viewpoints in American History (1922) had served as an inspiration for Foerster's volume, ostensibly advocates a social history based on the study of material conditions and dismissive of the personal, and redefines the work of literary history from this vantage point. In the process, he implies that what is at stake is a professional choice:

No one is disposed to question the important service which the esthetic critic renders to the study of letters, even though his dicta are usually rated higher by his contemporaries than by posterity. Undoubtedly, too, his criteria are often useful to the literary historian in arranging and classifying his materials. It remains, however, that literary criticism and literary history are two distinct branches of scholarship, each with its own point of view and technique, and having no more in common than, say, history in general and the study of ethics. Until the historian of letters frees himself from the domination of the literary critic, his work is certain to fall short of its highest promise. (Foerster 63-64)

9 This gesture of distinction between "two distinct branches of scholarship" is redefined by Clark in his own essay: 
the literature itself remains the true subject, and the proper focal center is finally the acknowledged masterpieces. If the literature of a certain territory or epoch is considerably below the esthetic par, but valuable as a mirror of contemporary conditions, it belongs to the field of the social historian rather than the literary historian. (Foerster 193)

Addressed in both of these essays, and in the volume as a whole, are the problem and pressure of disciplinarity, as objects of study are being redistributed according to the areas of expertise in which they rightfully belong. The very attempt to define what belongs to the "foreground" or to the "background" (Canby 82) of American literary history implies that it cannot be considered as the middle ground of interdisciplinary practice, yet, as illustrated by the reprint of Fred Lewis Pattee's 1924 essay for The American Mercury, "A Call for a Literary Historian," at the beginning of the volume, that literary history remains the defining project of the new field. In that respect, probably the most seminal aspect of Foerster's volume is its very inconclusiveness, and its failure to theorize interdisciplinary practice otherwise than by the juxtaposition of complementary or contradictory approaches, for it is all at once this failure and the maintained project of a literary-historical discourse that came to define (or undefine) the field of American literature.

${ }_{11} \mathrm{~A}$ compelling illustration of this persistent hesitation which pervaded American literary scholarship is the concurrent emergence, in the 1940s, of New Criticism, whose influence began to be truly felt in the American university at that time, and of the American Studies movement, which created its journal and its association at the end of that decade. ${ }^{v}$ On the one hand, the university embraced the formalist principles of New Criticism and made them the guiding principles of the disciplinary practice of literary study both for scholars and in the classroom; on the other hand, the disappearance of a historical approach to American letters was effectively preempted by the emergence of the American Studies movement. This is not to say that a disciplinary and an interdisciplinary option for the study of American literature existed independently from one other, for the interdisciplinary program of American Studies was one that accommodated the disciplinary precepts held from New Criticism. Winfried Fluck thus writes of the "myth and symbol school,"vi which, taking after Henry Nash Smith's Virgin Land: The American West as Symbol and Myth (1950), became American Studies' first paradigm, that its "amazing disciplinary influence" should "not only be attributed to its focus on American founding myths but, as the link between myth and symbol indicates, to a skillful combination of intellectual history and key formalist premises taken from New Criticism" (3).

12 It is somewhat ironic that Fluck speaks of the "disciplinary influence" of the myth and symbol school, since the "skillful combination" which he mentions reminds one of the "principled opportunism" that Smith himself, who was among the earliest American 
Studies scholars, prescribed as a remedy for that absence of method which defined the interdisciplinary project of American Studies (Smith 207). In his famous essay, "Can 'American Studies' Develop a Method?" (1957), Smith acknowledges the "rigorous narrowing of fields of inquiry" and the "specialization of interests that has been so marked a feature of scholarship in this country during the past half-century" (206), and admits that his own endeavor to go "beyond the usual limits of literary history or criticism" (198), "to widen the boundaries imposed by conventional modes of inquiry," has more to do with "daily struggles" than with building a route that others can follow (207). In the end, what he proposes is for a few willing individuals to work together against the grain of disciplinarity (207).

${ }_{13}$ His colleague and former student Leo Marx, whose Machine in the Garden: Technology and the Pastoral Ideal in America (1964) stands as one of the most enduring works of the myth and symbol school, would also insist that it is "neither possible nor desirable for American Studies to develop a method" so long as "the tacit definition for what constitutes an acceptable scholarly method" is derived from a scientific paradigm. Advocating instead a "humanistic" model of scholarship (Marx, "American Studies" 76), Leo Marx would incidentally develop what seems more like an individualistic model of transmission for American Studies, emphasizing the guidance of a few exceptional figures-gifted intellectuals who were able, through sheer originality, to invent their own interdisciplinary practice.

${ }_{14}$ It is perhaps an inheritance of the foreground/background rhetoric of Reinterpretation and its adjoining optical metaphors that while it conveyed a disciplinary imperative to "focus" it also left it as a virtual possibility that some privileged vantage points could exist from which an all-encompassing view remained available. For lack of any given window or lens through which to constitute its object, whose "wholeness" is the point, vii many American Studies scholars up until the 1990s would recurrently cite the example of a few visionary precursors, whose individual contributions eventually built the field. It is to these model interdisciplinary scholars that we turn next, in order to recover the tradition of interdisciplinarity implied by such constructions of exemplarity.

\section{Model Scholars: The Charismatic Ideology of American Studies}

${ }_{15}$ How does one transmit an interdisciplinary program which, to resist the disciplinary model, edicts no method to be followed? One of the ways in which the American Studies movement has responded to this dilemma is by erecting models, looking for them precisely inside the period when the study of American literature was still undisciplined. If it is a prerogative of disciplines to "create traditions that exceed their own histories" (Menand 116) by retrospectively associating pre- 
professional figures to their practice-as Menand shows for the use of T. S. Eliot by the New Critics-within an interdisciplinary project, this process may further become a way to oppose the professional models upheld by the modern university. From Gene Wise's "'Paradigm Dramas' in American Studies: A Cultural and Institutional History of the Movement" (1979) to Elaine Tyler May's "The Radical Roots of American Studies" (1995), the genealogical exercise that consists in identifying the founding figures or precursors of American Studies has been a staple of the movement. A few pioneering figures, self-made scholars of sorts, have thus been singled out as the visionary intellectuals who paved the way for an interdisciplinary study of America's culture. What is interesting, to come back to Menand's narrative, is that this interdisciplinary heritage is most often situated in the period that has been identified as the moment of specialization and professionalization, but which, as we saw, remained a moment of relative indefinition where the study of American literature is concerned.

${ }_{16}$ Among those figures, one of the earliest would be Moses Coit Tyler, who authored a History of American Literature during the Colonial Time, 1607-1765 (1878) and a Literary History of the American Revolution, 1763-1783 (1897) in the retrospective vein identified by Stokes, and was appointed at Cornell in 1881 to the first chair in the history of the United States. In a letter from 1872 quoted by Michael Kammen, Tyler even envisioned "the establishment of a Professorship of American Literature and History" (Kammen 66), indicating thereby that the separation between these fields left him with no existing position which could accommodate his range in the new professional culture of the university. Equally ill-suited to disciplinary categorizations is the often cited career of Vernon Louis Parrington, who taught in departments of English but whose three-volume Main Currents in American Thought (1927-1930) won the Pulitzer Prize for History. His own contribution to Foerster's volume, Reinterpretation, viiis one of the few that apply the socio-historical approach advocated by Schlesinger, yet this does not mean that Parrington can be associated with any given faction or group. Conversely, he stands as a compelling example of the lonely scholar, whose commitment to an unprecedented task seems somewhat heroic. Acknowledged as a founder of American Studies, he is not for that matter credited with the elaboration of a collective enterprise. Gene Wise explains that, on the contrary, Parrington's importance for American Studies lies in his isolation:

[Main Currents] lacked all the institutional supports now felt necessary to the enterprise of scholarship. It was simply an act of human intellect reduced to the barest essentials-a single mind grappling with materials of American experience, and driven by concentrated fury to create order from them. And that, I would say, is the elemental "paradigm drama" of American Studies-elemental not only in being first, but also in embodying a characteristic urge of persons drawn to the movement from Parrington's day on to ours. (300, italics in the text) 
17 That same elemental characteristic is emphasized by Leo Marx in "On Recovering the 'Ur' Theory of American Studies" (2005), when he insists on the debt American Studies holds to "an odd lot of gifted men -and some women-... untrained, unaffiliated, unspecialized writers whose common trait was a fascination with the idea of America." Marx goes on to name the

self-appointed men and women of letters, deviant professors, independent scholars, public intellectuals, and wide-ranging journalists and poets like Thorstein Veblen, Van Wyck Brooks, Waldo Frank, Constance Rourke, V. L. Parrington, W. E. B. DuBois, Charles and Mary Beard, Lewis Mumford, Edmund Wilson, William Carlos Williams, Matthiessen-the list could of course be much longer. Many of these writers worked in the shadowy borderland between Academia, Bohemia, and Grub Street. Most lacked academic credentials. (128)

Electing mostly figures that are associated with the 1910s and 1920s, Marx's essay is especially interesting for the way it insists on these "borderland" scholars, thus equating the former promise of interdisciplinarity with extra-disciplinarity or un-discipline ("deviant") and speaking in fact of "[t]he singularity of American studies as a nondiscipline," meaning "that its founders did not believe they were training students to think of themselves, as historians did, as proud bearers of that scholarly legacy-a tradition of historiographical practices and theoretical wisdom-that goes back to Herodotus and Thucydides" (127). The amusing blind-spot of Marx in this essay is that he is of course in the process of building a "scholarly legacy" himself, albeit one that seems incompatible with a disciplinary premise. What differentiates his own list of model interdisciplinary intellectuals from the way historians hold on to the examples of Herodotus and Thucydides is the contrasting ways in which these sets of models are made available for the transmission or reproduction of a given knowledge and method. In Marx's case, we seem to be dealing with the establishment of what sociologists, and Pierre Bourdieu in particular, would call a "charismatic" model of influence (Bourdieu and Passeron 1964; Bourdieu and Passeron 1970; Bourdieu 1981), where the singling out of exceptional individuals and performances becomes a way of defining education as the passing on of a gift, and as an interpersonal process of initiation.

${ }_{19}$ Especially interesting for our purpose is the way Bourdieu explains the influence held by what Max Weber had called the charismatic individual as the product of "an inaugural act, accomplished in a situation of crisis, in the void and the silence left by institutions" ix (Bourdieu 18). The loose genealogy established by Marx and by others can indeed be seen as the retrospective consecration of a moment of institutional void, here a moment when the disciplinary imperative was not yet enforced and had not yet segmented the study of American culture. Moreover, when the history of American Studies is imagined as this sequence of individual feats, it is indeed a series of inaugural acts 
yet unhindered by institutional restrictions that are being held as the touchstones of original interdisciplinary practice, which is not made available through any given method but rather through an act of allegiance or faith Marx has called "believing in America" ("On Recovering" 120). While the inaugural act should be re-enacted, the example it sets is not one that can be learned from, much in the same way that "the gestures of a surgeon, a soloist or an acrobat," which are "predisposed to symbolically manifest the unique qualities of the performer or the performance," can be "accentuated" to prevail oneself of the "elegance of ostensibly renouncing the institution's most visible protections"x (Bourdieu and Passeron, La Reproduction 158).

20 For Bourdieu and Passeron, what happens in the case of a charismatic ideology is a reciprocal "mystification" of the roles of the professor and the student, where the relationship between "pedagogue and apprentice" is in fact replaced by the relationship of the "elect" among themselves. Such a process of mutual mystification, by "allowing professors to see themselves as masters communicating a whole culture through a personal gift" obeys the "logics of a system" that seems to work to "train cultured men rather than professional men"xi (Les Héritiers 88). In the case of American Studies, this relationship of the elect among themselves exists virtually in the continuity instituted between the precursors of the movement and those who set them as examples. But it is also interesting to note how the foregoing of the classical classroom experience is relevant to the very foundation of American Studies, if we keep in mind that the movement was born out of a number of Ph.D. programs invented in the 1930s-not the least of which was Harvard's doctorate in the History of American Civilization, which Henry Nash Smith was the first to complete in 1940-and such programs are, by definition, structured by an interpersonal relationship where the mutual mystification of the roles of student and teacher is facilitated. As we will see, an insistence on these interpersonal relationships reappears in other interdisciplinary programs combining history and literature. More generally, if we apply the charismatic ideology described by Bourdieu to the interdisciplinary project of American Studies, it helps us see how an allegiance to "unaffiliated" figures has in fact been one way to institute an alternative model of affiliation and the pedagogical ideal of a more immediate transmission. Thus, while the premise of American Studies seems to be that, for lack of a given method to be transmitted, "interdisciplinarity teaches itself'"xii this idea of a relative institutional void has in fact been both authorized and remedied by the tradition of self-made scholars recovered from the beginning of the century. 


\section{Models of Education: From Harvard's "Hist and Lit" (1906) to Columbia's “HiLi” (2011)}

21 In the case of American Studies, the acknowledgment of key figures from the beginning of the twentieth century serves to identify an interdisciplinary turn of mind and to implicitly prescribe a pedagogical model, which can be described as charismatic. The period that is revisited becomes a moment of reference for the elaboration and the transmission of an interdisciplinary tradition, which is traced back to the institutional "unaffiliation" or "disaffiliation" of a few scholars who preceded or resisted the emerging logic of specialization. If it is the idiosyncratic aspect of their careers that is highlighted in this instance, this should not lead us to discard the academic forms taken by a resistance to the new university culture in these years, and what their legacy might be. Thus it is, for example, that the names of F. O. Matthiessen and Perry Miller often feature in American Studies' loose genealogy, with much attention given to their individual contributions to the field in the 1930s and after, but usually no mention is made of the fact that these two prominent scholars taught together in Harvard's History and Literature program, created at the beginning of the twentieth century and claimed as "the major precursor of twentiethcentury programs in American Studies" (Self 137). It is by looking into this program and comparing it with Columbia's much more recent History and Literature masters' that we return to the significance of the institutional context of the beginning of the twentieth century for the American interdisciplinary study of history and literature.

22 Although the Harvard program was not devoted exclusively to the study of America, its founder, Barrett Wendell, was a scholar of American literature, whose important Literary History of America came out in 1900, a few years before the inauguration of History and Literature in 1906. Wendell created Harvard's first concentration and its elaborate system of tutorships, "the heart of the program" (Ireland), to reinstate the guidance he felt had been lost with President Charles W. Eliot's reform introducing an electives system for undergraduates. Whether or not those tutorships reinstate symbolically the institutional function of in loco parentis abandoned by the modern university, they meant-and still mean-that the interdisciplinary program invented by Wendell was structured by the interpersonal relationship between student and teacher-a "model of education that every student deserves," as one of them put it on the occasion of the program's recent centenary (Ireland). The program, in fact, is not meant for every student, and its highly selective requirements still help ensure today that the pairing of staff to student remains possible. The institutional emphasis laid on these relationships is reminiscent of the charismatic ideology discussed earlier, and indeed can help us see again how interdisciplinarity makes up for its lack of method. But where the charismatic ideology of American Studies could be found in its loose 
and scattered genealogy of self-made scholars, here some of their names are brought together in relation to the Harvard program: Matthiessen (who served as chair), Miller, Leo Marx, and Arthur Schlesinger Jr., not to mention scholars who had studied under Wendell if not in his new program, such as Van Wyck Brooks or Parrington. Claudia Stokes has remarked that "institutional affiliation remains one of the most potent and unremarked-upon contexts for the production of knowledge" (184), and indeed in this case to list the names associated with Harvard's program is to constitute anew a distinguished American tradition of interdisciplinarity. Which is not to say that interdisciplinarity, or, in the case of Schlesinger, the figure of the public intellectual, were invented at Harvard, but to insist on the institutional traditions and pedagogical relationships that can account for the transmission of a vision of interdisciplinarity.

${ }_{23}$ Columbia's own History and Literature curriculum ("HiLi"), a Master of Arts program this time, opened in September 2011 in Paris. It shares with the Harvard concentration its very small classes and tutorship system, but the similarities seem, at first, to end there. Where the history of the Harvard program is marked by Wendell's reactionary politics, the Columbia masters' stresses innovation and reactivity to recent debates on interdisciplinarity. Where the influence and prestigious character of the Harvard program is linked to the phenomenon of institutional affiliation that we mentioned, the overseas location of the Columbia initiative acknowledges the influence held rather by the program's partner institutions, the École des hautes études en sciences sociales (the EHESS, which incidentally does not follow a disciplinary organization) and the École normale supérieure (ENS). When I interviewed the program's administrator, Christine Valero, and its director, Joanna Stalnaker, a professor of French, they insisted on the special vitality of interdisciplinarity debates in France and Europe, and on the opportunity of having faculty members, such as the EHESS scholars Judith Lyon-Caen and Dinah Ribard, whose very texts are taught in the program, xiii with Stalnaker adding that "the thing I really want [the students] to come away with is that this is a site of contestation, that these are boundaries that are being negotiated and that are being negotiated in different ways," and that in this perspective, contending with debates that are held outside the US only fosters this displacement of boundaries and the "intellectual flexibility" that Stalnaker says is the take-away of the program.

${ }_{24}$ But when I asked Stalnaker what it was that this new program might still owe to Columbia's own traditions and history, and, therefore, whether this new commitment to interdisciplinarity could be informed by a phenomenon of institutional affiliation such as the one that can be read into Harvard's program, her answer brought us back to the early twentieth century. Stalnaker explained that, for her, the Columbian tradition to which HiLi was tributary was its own centenary Core program, an intensive general education requirement, which every undergraduate has been taking since the First World War, and whose 
major courses are now called Literature Humanities and Contemporary Civilization. The Core, she explained, has a "tremendous impact" on professors at Columbia, where every junior professor in the Humanities is required to teach in the Literature Humanities great books course of the core curriculum. Stalnaker explained that "this is hugely important... because it means we're all interdisciplinary," citing the case of professors who "get the message from the fact that we have the Core program" that, in their own courses, they can teach subjects that lie outside their area of expertise. She added that the teaching-style adopted for the core curriculum, where groups are capped at twentytwo students and the class is discussion-based, is one that was also adopted in HiLi.

25 In part, then, it is the sentiment of institutional affiliation, "the fact that we have the Core program," that authorizes Columbia's interdisciplinary initiative. This mention of Columbia's Core program is meaningful, because it brings us back to the same moment in the 1920s when the pressure of disciplinarity caught up with the study of American literature, and when John Erskine devised the Great Books course that was to become Columbia's current Literature Humanities. Erskine had been one of the editors of the first collaborative literary history of America, the Cambridge History of American Literature (1917-1921), though his later commitment to the Great Books idea, which he expressed in The Delight of Great Books (1927), was not in itself an endeavor to bring American literature into the classroom. In fact, the only Americans in the curriculum he devised: Josiah Royce, George Santayana, William James, and Henry George, are philosophers, not writers. It was, however, an attempt to resist the pressure of specialization to which American literature itself was succumbing. In that sense, it does seem significant that Wendell and Erskine, both academics who historically influenced a commitment to interdisciplinarity in their institutions, were American literature scholars-as if their propositions were a way of upholding the range and scope to which they had been entitled in their own field of interest, and which had come to define that field, but which were being renegotiated in the new university culture. More generally, the interdisciplinary ambition of the Great Books curriculum arose from a conservative impulse similar to the one that led Wendell to found Harvard's History and Literature concentration in 1906, and both endeavors should be understood within the specific institutional context of the early twentieth century.

26 The historical heritage that lies behind both the Harvard and Columbia programs confirms that, if a reference to the period from 1870 to 1915 can explain the current state of the American university, the period from 1900 into the 1920s can certainly be constituted as a point of reference for the institutionalization of interdisciplinarity as a counter-proposition to the specializing trend then advocated in American research universities. What is left out when the history of American universities is decided in 1915 is the special, yet undecided 
case of American literature, and we hope to have shown that the very delay after which it integrated the new university culture is what informed, and still influences, an American commitment to the interdisciplinary study of history and literature.

27 The study of American literature gained academic recognition sufficiently late to be defined, in the meanwhile, as the one remaining province of the generalist, as opposed to the specialist. In many ways, interdisciplinary considerations of history and literature remain committed to the dream of the generalist, which seems perpetuated again through a process of institutional affiliation. Thus it is, for instance, that Jill Lepore, recently the chair of Harvard's History and Literature program, and upholding her own dream of becoming a "public historian" (Humanities), seems a fair modern-day example of the generalist. While this might mean hanging on to "unfashionable arguments" (Humanities), as she puts it, Lepore, a historian but also novelist, remains convinced that "the study of American history is inseparable from the study of American literature" (Lepore 15), and, incidentally, that historical scholarship is indissociable from the art of writing. She is also committed to a "civic-minded" scholarship, such as the one she presents in the on-line journal she devised, CommonPlace. ${ }^{\text {iv }}$ Her colleague Louis Menand, with whom she co-taught the introductory course to American Studies at Harvard, is another, somewhat similar, present-day exemplar of the generalist. A student of Lionel Trilling's at Columbia (one of the eminent scholars associated with the Core program), and recently on Harvard's committee to reform the university's general education curriculum, Menand additionally bears a similarity with Parrington for being a professor of English who won the Pulitzer Prize in History, for The Metaphysical Club: A Story of Ideas in America, in 2001. Insisting like Lepore that his primary calling is that of the writer (Williams), Menand is also, like Lepore, a staff writer for The New Yorker, so that while he remains skeptical of the possibility to truly institute interdisciplinarity in the modern university, his own individual practice certainly illustrates an attempt by an academic to reach out to a "larger culture." It is also reminiscent of many a generalist's institutional polyvalence between the world of journalism and the world of academia, revealing in another light what interdisciplinarity's discontents with professionalization (and its reverence for "borderland" figures) might owe to a nostalgia for this figure of the generalist. If the turn to disciplinary organization in the university coincided more largely with what historian Richard Hofstadter has called "the rise of the expert" (chapter 8) in the United States, it can be said that from the early twentieth century onwards history and literature programs have maintained an alternative to this reign of expertise by passing on a historical anxiety focused on the disappearance of the generalist. 


\section{BIBLIOGRAPHY}

Author's interview with Joanna Stalnaker and Christine Valero, 17 December 2014, Paris.

---. “The Public Historian: A Conversation with Jill Lepore.” Humanities 30.5 (Sept-Oct. 2009). Web. 1 May 2015 http://www.neh.gov/humanities/2009/septemberoctober/conversation/the-publichistorian

Bourdieu, Pierre, and Jean-Claude Passeron. Les Héritiers : les étudiants et la culture. Paris: Les Éditions de Minuit, 1964. Print.

---. La Reproduction: éléments pour une théorie du système d'enseignement. Paris: Les Éditions de Minuit, 1970. Print.

Bourdieu, Pierre. "La représentation politique (Éléments pour une théorie du champ politique)." Actes de la recherche en sciences sociales 36-37 (Feb-Mar. 1981): 3-24. Print.

Canby, Henry S. "Review of The Reinterpretation of American Literature by Norman Foerster." American Literature 1.1 (March 1929): 79-85. Print.

Foerster, Norman, ed. The Reinterpretation of American Literature: Some Contributions Toward the Understanding of Its Historical Development. New York: Russell \& Russell, 1959 [1928]. Print.

Fluck, Winfried. “American Literary History and the Romance with America.” American Literary History 21.1 (Spring 2009): 1-18. Print.

Graff, Gerald. Professing Literature: An Institutional History. Chicago: U of Chicago P, 1987. Print. Hofstadter, Richard. Anti-Intellectualism in American Life. New York: Knopf, 1963. Print.

Ireland, Corydon. "History and Literature Program Celebrates 100 years." Harvard University Gazette. 12 October 2006. Web. 1 May 2015.

http://news.harvard.edu/gazette/2006/10.12/01-histlit.html

Kammen, Michael. "Moses Coit Tyler: The First Professor of American History in the United States.” The History Teacher 17.1 (Nov. 1983): 61-87. Print.

Lepore, Jill. The Story of America: Essays on Origins. Princeton and Oxford: Princeton UP, 2012. Print. Lyon-Caen, Judith, and Dinah Ribard. L'Historien et la littérature. Paris: La Découverte, 2010. Print.

Marx, Leo. “American Studies. A Defense of an Unscientific Method.” New Literary History, 1.1 (Oct. 1969): 75-90. Print.

---. “On Recovering the 'Ur' Theory of American Studies.” American Literary History 17.1 (Spring 2005): 118-134. Print.

May, Elaine Tyler. “'The Radical Roots of American Studies': Presidential Address to the American Studies Association, November 9, 1995.” American Quarterly 48.2 (June 1996): 179-200. Print.

Menand, Louis. The Marketplace of Ideas: Reform and Resistance in the American University. New York: W. W. Norton \& Company, 2010. Print.

Renker, Elizabeth. The Origins of American Literature Studies: An Institutional History. Minneapolis: U of Minnesota P, 2007. Print.

Self, Robert. Barrett Wendell. Boston: Twayne, 1975. Print. 
Shumway, David R. Creating American Civilization: A Genealogy of American Literature as an Academic Discipline. Minneapolis: U of Minnesota P, 1994. Print.

Smith, Henry Nash. “Can ‘American Studies' Develop a Method?” American Quarterly 9.2, part 2 (Summer 1957): 197-208. Print.

Stokes, Claudia. Writers in Retrospect: The Rise of American Literary History, 1875-1910. Chapel Hill: U of North Carolina P, 2006. Print.

Vanderbilt, Kermit. American Literature and the Academy: The Roots, Growth and Maturity of a Profession. Philadelphia: U of Pennsylvania P, 1986. Print.

Wald, Priscilla. “The Provincialism of Time.” Early American Literature 50.1 (2015): 63-80. Print.

Williams, Jeffrey J. "New New York Intellectual: An Interview with Louis Menand.” The Minnesota Review 52-54 (2001): 141-158. Web. 1May 2015.

http://www.theminnesotareview.org/ns52/menand.html

Wise, Gene. " 'Paradigm Dramas' in American Studies: A Cultural and Institutional History of the Movement.” American Quarterly 31.3 (1979): 293-337. Print.

\section{NOTES}

i. In an interview for The Minnesota Review, Menand said: “Given that's [interdisciplinarity] where scholarship is going, and given what new study-centers represent, the credentialing process ought to move in that direction instead of staying with disciplines that no one really takes seriously anymore. But I don't actually see that happening" (Williams).

ii. The ALG was constituted in 1921, when the MLA created subdivisions for its various fields, and American literature became the last of the eleven sections constituting the English field. The group's notable figures were professors Fred Lewis Pattee, Killis Campbell, Arthur Quinn, Norman Foerster and Jay B. Hubbell. The sum of their efforts, the journal American Literature, was founded in 1929.

iii. It was Charles Anderson, a Melville specialist.

iv. See for instance Wald for a recent estimate of Reinterpretation's enduring significance to the study of American literature.

v. The American Quarterly was founded in 1949, the American Studies Association in 1951.

vi. The "myth and symbol school" is the name given to the dominant theory in American Studies up to the 1960s. Its premise was that the recurrent motifs, symbols and themes found in American texts could be taken to express the unique characteristics and history of the national culture. Major works which upheld this premise were Smith's Virgin Land and Leo Marx's The Machine in the Garden.

vii. See for instance Smith for a discussion of this phrase "as a whole," which also serves to sum up the methodological problem of American Studies: "The problem of method in American Studies arises because the investigation of American culture as a whole does not coincide with the customary field of operations of any established discipline" (Smith 197).

viii. It consists of the essay entitled "The Development of Realism" (Foerster 139-159).

ix. "le produit d'une action inaugurale, accomplie en situation de crise, dans le vide et le silence laissés par les institutions". Translations are mine.

x. "le professeur doit être doté par l'institution des attributs symboliques de l'autorité attachée à sa charge [...] pour pouvoir se donner l'élégance de renoncer ostentoirement aux protections les plus visibles de l'institution en accentuant les aspects d'une tâche qui, comme les gestes du 
chirurgien, du soliste ou de l'acrobate, sont prédisposés à manifester symboliquement la qualité unique de l'exécutant et de l'exécution".

xi. "L'expérience mystifiée de la condition étudiante autorise l'expérience enchantée de la fonction professorale : à la mise en rapport, techniquement aménagée, entre un pédagogue et un apprenti peut se substituer la rencontre d'élection entre des élus. Parce qu'il permet aux professeurs de s'apparaître comme des maitres communiquant par don personnel une culture totale, ce jeu des complaisances réciproques et complémentaires obéit à la logique d'un système qui, comme le système français en sa forme présente, semble servir des fins traditionnelles plutôt que rationnelles et travailler objectivement à former des hommes cultivés plutôt que des hommes de métier."

xii. This expression is here borrowed and adapted from Gerald Graff's analysis of "the humanist myth," which holds that "literature teaches itself" (1-15).

xiii. Lyon-Caen and Ribard have worked on the history of the social sciences and on the relationship between literature and history; they recently co-authored L'Historien et la littérature, La Découverte, 2010.

xiv. See http://www.common-place.org

\section{ABSTRACTS}

Interdisciplinary study, because it runs counter to the dominant culture of specialization and professionalization upheld within the modern research university, is often presented as an innovative and experimental renegotiation of an outdated organization of knowledge. This essay qualifies such claims about the forward-looking ambitions of interdisciplinarity by examining the institutional history and traditions which they tend to obscure. Taking on the special case of the study of American literature, this essay argues that its belated recognition as a discipline, in the 1920 s, framed it in the meantime as the one remaining province of the generalist amidst the rise of expertise that had come to characterize academic culture as of the end of the nineteenth century. If this delay helps explain ongoing commitments to an interdisciplinary study of American literature and history, the essay shows more specifically how this interdisciplinary project is buttressed by references to scholars and programs from the early twentieth century, a moment which is cast not as the decisive turn towards disciplinarity but as the last moment of indecision in which to recover the dissident forms, methods and pedagogy of interdisciplinarity. Even while interdisciplinarity seems to "teach itself", relinquishing the narrow set of tools and methods through which a discipline trains its practitioners, it is by acknowledging some of the backwards-looking trends in the interdisciplinary study of history and literature in America that we can recover the ideals of scholarship it seeks to transmit.

\section{INDEX}

Keywords: American studies, Arthur Schlesinger, Barrett Wendell, charismatic ideology, Columbia, Harvard, history, interdisciplinarity, John Erskine, literature, Norman Foerster, university, Vernon L. Parrington 